\title{
Evaluating the impact of branding on music streaming services such as Spotify, Apple Music and Tidal have had on consumers
}

\author{
Mehak Ghulam Mohammad( M.Phil) \\ Faculty Of Management Sciences Indus University \\ Email: mehak.gu1982@gmail.com \\ Poonam Riaz (M.Phil) PhD In Process \\ Faculty Of Management Sciences \\ Indus University \\ Email: poonam.riaz@gmail.com \\ Rameez Farooq(MBA) \\ Email: rameezfarooqessani@gmail.com \\ Executive Inventory \& Logistics \\ Artistic Milliners (Pvt.) Ltd. \\ Entrepreneur (partnership): Ozone.com.pk \\ Ahsan Adhia (MS) \\ Executive Marketing \& Finance \\ Organization: Al Huda Multipurpose (Pvt.) Ltd. \\ Email:ahsanadhia@yahoo.com
}

\begin{abstract}
The aim of this study was to evaluate the impact of branding in the music streaming industry while considering the three companies, which include Spotify, Tidal and Apple Music. Following the quantitative research methodology, the researcher survey 80 music listeners in the university. Based on the results, the responses of participants were oriented towards Spotify. In regards to the preferences of music streaming services, Spotify lied on the first preference. Meanwhile, Apple Music lied at the second number. Whereas, Tidal lied on the third number followed by a minimal amount of responses for its services chosen by the consumers. Branding has main stake in the music streaming services industry. The evaluation of branding of three brands such as Tidal, Apple Music and Spotify provide the differing results. Tidal and Apple Music have good branding and its impact on the consumer choice. However, Tidal followed by Apple Music has lower impact when it comes to compare the results and responses with Spotify.
\end{abstract}

Keywords: branding, music streaming services

DOI: $10.7176 / \mathrm{IKM} / 11-4-09$

Publication date:August $31^{\text {st }} 2021$

\section{Introduction}

A purchase decision is a choice made by the consumers in everyday situations about the things on which they consider worthy to spend their money. This is what the consumers buy the products and services and share them with their families and friends, bring to work and much more. Such decisions are made by the consumers on the basis of two factors. The first factor is their need to buy any product or service, the second factor is how the seller has established its image of the product (Truong et al., 2017). A market contains multiple sellers and multiple buyers. The multiplicity of both is not an issue. However, the choice for the multiple options either in the form of customers or in the form of sellers is a challenging situation for both when making decisions. Sellers push their products, while the buyers accept them only if they are satisfied and are intervened through any stimuli.

Such stimuli can be in the form of marketing, advertising and promotions by the companies that try to push their products and services. The same stimuli has been termed as the branding, which, in turn, influences the buying decisions of consumers. Rather it attracts them to opt for the suggested products and services. Branding is not a sufficient concept with the branding strategies (Mooney, 2015). The branding strategies are the aids and instruments of branding for the organizations to establish the demand for their products and services. 
Considering this situation, the researcher aims to investigate how the branding strategies of the three companies such as Tidal, Apple Music and Spotify are influencing the consumers.

\subsection{Background of the Music Streaming Brands}

\subsubsection{Spotify}

According to Kim et al. (2017), Spotify Ltd. is a music streaming platform. It was created by Swedish Company called Spotify Technology, which is located in Stockholm, Sweden. The company was enlisted on the New York Stock Exchange in 2008 and now it is serving in more than 75 countries in the world. The share of this company in the music streaming sector is $36 \%$.

\subsubsection{Apple Music}

Apple Music is a music and video streaming brand. It is the subsidiary of Apple Inc. opened in 2015. Its music streaming services are served in more than 100 countries in the world. The share of this brand in the music streaming sector is $19 \%$ (Kim et al., 2017).

\subsubsection{Tidal}

It is a subscription-based music and video streaming brand where it is owned by a huge superstar Jay-Z. It is a Norwegian-based brand and has more than 175000 videos. The streaming of Tidal is viewed in more than 50 countries in the world. The company was established in 2014 (Kim et al., 2017).

\subsection{Background of the study}

Since the rise of digital platforms for media distribution, the music industry has had tremendous changes in music streaming. Before the new advanced technology, music was majorly distributed through (Compact Disks) CDs and other storage devices (Saboo et al., 2016). Online music downloading replaced traditional offline music. However, with the improved technology, online music downloading has been replaced by music streaming (Moreno-Munoz et al., 2016). As a result, there has been a rise in the number of music streaming service providers. This is attributable to the widespread use of mobiles phones and the accessibility of wireless networks. The streaming service allows people to listen to music without downloading the tracks to a device or owning the tracks (Mooney, 2015). This feature of music distribution has helped the listeners to save on storage and the cost of downloading.

There are two ways a music streaming service provider can base his branding. The branding is dependent on the revenue model and streaming mode. The revenue source may be based on an advertisement-based free model, which sells advertisement while offering free of charge services, or on a subscription-based streaming model, which offers a subscription of services with no advertisements (Wlomert \& Papies, 2016). Since all companies are based on either of the two options, a competitive service provider has to create a niche beyond the basic revenue categorization. This is achievable through developing a unique brand. Creating a brand is not a guarantee for profitability. The action of creating awareness is the most critical since it determines the market share and profitability (Chen et al., 2017).

Consequently, branding makes a product or services unique and distinguishable from other similar products or services. A good brand should consider what consumers prefer for music streaming. Therefore, companies ought to make efforts in guarding their brand image. Therefore, branding and brand awareness strategies have become the best option to sustain a business among several competitors (Brown, 2016). Branding creates a memorable impression on consumers and a good reputation (Lee et al., 2016).

Most music streaming companies do not know how to utilize branding in their business. They just enter the market because the business niche seems profitable and is an easy way of earning money. Some firms have created a brand but do not know how to create awareness or sustain the branding (Liu, and Zhang, 2017). In addition, some emerging firms have the potential of being the largest competitors but lack the branding and brand awareness skills and know-how. They rarely consider the most crucial business aspect of effective marketing strategies. This makes most companies have low performance, low profitability, and quality and fraud issues. These problems destroy a firm's reputation and break the customers' loyalty (Philpott, and Doran, 2016). Recovery of the initial company's image after experiencing quality or royalties issues is a real struggle of the company (Hracs, \& Jansson, 2017).

There is increased brand name destruction. This is attributable to the increased labels and rights fraud in the music streaming. Each music has a tangible price tag in which the right and label owners should be paid on a pro-rata basis (Fang, 2018). Most companies fail to adhere to the payment terms due to the luring profits and consequently tarnish their brand image. With several music streaming service providers being associated with 
fraud, a well-guarded brand should avoid being charged with royalty cases. Most consumers consider the reliability, affordability, and the quality of the downloadable music. Some service providers offer low-quality music and most companies are not satisfying customer core preferences. This poor customer service can be alleviated by efficient and effective branding (Gerogiannis et al., 2016).

\subsection{Problem Statement}

Currently, the music streaming industry has become turbulent and more competitive with numerous service providers getting into the market each year. The high number of service providers crowding the market and increasing competition (Kim et al., 2016). Since technology advancement has led to the rise of numerous streaming providers, the competition in the streaming sector has consequently risen too. For a firm to stand out from its competitors, it ought to strategize on creating a unique brand that will allow gaining of a competitive advantage over the others (Leyshon et al., 2016). Moreover, each provider is aiming at offering the best music features and affordable offers. To retain customers and gain more incoming customers, the prevalence of branding strategies is important. Keeping the importance of branding in view, this study is aimed to address how the branding influences the selection decisions of the users of music streaming services of three companies such as Spotify, Apple Music and Tidal.

\subsection{Objectives of the Study}

The aim of this study is to evaluate the impact of branding in the music streaming industry while considering the three companies such as Spotify, Tidal and Apple Music. Following were the aims of study.

- To examine the importance of branding in music streaming services

- To evaluate the branding strategies of music streaming services such as such as Spotify, Apple Music, and Tidal

- To evaluate the preference of consumers for the use of any three companies followed by their branding

\subsection{Research Questions}

- What is the importance of branding in music streaming services?

- What are the branding strategies of music streaming services such as such as Spotify, Apple Music, and Tidal?

- What is the preference of consumers for the use of any three companies followed by their branding?

\subsection{The Significance of the study}

The study will be helpful to the music streaming industry. The service providers will be able to know the importance of branding, and branding problems. New emerging companies will learn about the essence of branding while reviewing the outcomes and impact of the strategies of three companies (Spotify, Apple Music and Tidal) selected before getting into the market. Also, poor performing companies can learn their branding weaknesses and improve to gain a competitive advantage since the paper discusses the industry problems and solutions. Consumers will know what to consider when searching for the most reliable, affordable, and quality services. The study can be helpful to business students and other industry sectors, who can learn branding tips and concepts.

\section{Review of literature}

\subsection{Theoretical Literature}

This section of the literature review discusses the theoretical literature by looking at the branding strategies of companies chosen, an overview of music streaming services, and determinants of brand development. The section also highlighted the role of branding in brand development while discussing the impact of branding on consumer choice. 


\subsubsection{Apple}

Apple brand strategy takes some great things. Apple is focused exclusively on high-quality products. They do not sell cheaper models of a smartphone apple. Samsung, for example, is producing some types of smartphones, including some cheap models. Apple made its users who are not ready to opt any other competitive brand than apple or are highly satisfied with Apple very clear as it rejected to produce mediocre good-enough products. The prices of apple products are maintained very high which portrays a curious image in the people's minds, Truong and Klink et al. (2017). The products of Apple are always sleek and attractive. Moreover, the graphics used in advertising are also very attractive.

A secret game is used by Apple. The top secret of Apple Company is, they hide the future Apple products. It was even mentioned by Tim Cook in an interview that the number of secrets held by Apple is more than those held by CIA. There are several bloggers who often disclose the latest news about Apple yet there is a huge sum of people who constantly try to figure out the shape and specifications of the upcoming iPhone. Media outlets such as Forbes and Bloomberg disclose such posts about iPhone. So, as soon as a new product by Apple is launched, people rush to approach it in order to be the first of its users, Ottman (2017).

\subsubsection{Spotify}

Spotify is a freemium service: it offers free basics with ads or limitations, but other features such as better streaming and music downloads are offered with paid subscriptions. The unique value proposition of Spotify is to provide users with complete control while allowing them to access any song on demand which is only for $\$ 10$ per month. The company also provide a free option which offered greater than simple streaming in radio style (Glantz, 2016). Spotify revolutionized how people listened to music. It became popular with consumer music services because it puts the management well in the hands of the user and allows them to select specific songs and create playlists.

One of its features reduced the friction of adoption: It allowed users to upload local laws so they did not have to leave their own libraries and playlists behind to make the Spotify (Meier, 2017). Spotify filled the need for consumers but was able to control its growth. Rolling out with an invitation-only system that helped the company generate a buzz and increase demand through perceived lack. Spotify attracts technically loving early adopters. It integrates with today's share of the world: it's easy to share because every song, album, and playlist have a unique URL. And it also gives users the need to share music with their friends in the social arena (Frew and McPherson, 2015).

\subsubsection{Tidal}

In the beginning, Tidal was positioned as an artist owned service in the market. It was released in autumn in 2015 as soon as it was bought by Jay-Z from Aspiro for 56 million dollars. The management of the company was reshuffled by Jay-Z. Its music files were named as "Lossless" as they were completely different from its competitive brands. The quality of Lossless music is similar to that of CD audio, McDowell (2015). Paying 19.99 dollars per month, files having audio of 1,411-kilobytes-per-second can be enjoyed by the subscribers delivered by FLAC format. Despite this, standard quality files of 96 to $320 \mathrm{kbps}$ can also be accessed by the subscribers for 9.99 dollars. The mission used by artists is important for the marketing rhetoric used by Tidal. The current celebrity stakeholders of Tidal are Beyonce, Usher, Arcade Fire, Rihanna, Alicia Keys, Nicki Minaj, Calvin Harris, Madonna, Chris Martin, Kayne West, Deadmau5, Jay Z, Daft Punk, J. Cole, Jack White, and Jason Aldean. Apart from these, Softbank, who is the huge investor of Sprint agreed to buy a minimum stake last April and projected the cost of Tidal as \$250 million, Masuda and Bookman (2018).

\subsection{Music Streaming Services}

The music industry was aware of a number of technological inventions in the past few decades. This industry has continuously been reinventing ever since the vinyl, the radio, and CDs were invented. All these inventions are considered to be maintaining inventions. When the industry digitalized, it destroyed many existing business models. This recovery is being made through new business models which tends to generate income on the internet. In the beginning, payment was made on per album or per track basis but now, it is being made on the basis of interactive streaming, Leyshon and Thrift et al. (2016).

Streaming music or an audio refers to being able to hear a song without having to download it. Apple Music, 
Spotify, and Pandora are a few music services which use this method to allow their users to enjoy the songs on any device without having to download it. Furthermore, the business model of streaming was detected with a doubtful approach. Spotify is going down every year as it has some license issues and has a huge amount of outstanding payment to the copyright holders. Therefore, Spotify is facing difficulty in securing long-term financial survival as it has low margins, Naveed et al. (2017).

\subsection{Determinants of Brand Development}

In order to create a brand, it is necessary to increase the distinct values of a core product so as to make it indifferent from the competition. Also, the comprehension of emotional as well as functional values of the customers shall be pin pointed. There are seven factors in creating a brand:

\subsubsection{Quality}

It is important for the core product to be of high quality. The basic requirements with respect to functions shall be possessed by the product. The brands whose quality is high are able to acquire high profit as well as greater market share than those with poor quality. Also, it is important for a brand to know the viewpoint of customers while judging the quality of a product. There are even some customers who do zero suspect before buying a product, Gomes and Fernandes et al. (2016).

\subsubsection{Positioning}

In order to create a unique position in the market, the targeted market shall be chosen carefully which would eventually draw a different picture in the customer's minds. The brand name, delivery, image, packaging, service, guarantees, and design are a few things which help to achieve this, Iyer and Davari (2018).

\subsubsection{Repositioning}

Repositioning is needed to sustain the brand position as new opportunities arise with the passage of time. If a brand is not able to fulfill the customer's needs and circumstances with the changes in the market, it may be marked as irrelevant, Davcik and Vinhas da Silva et al. (2015).

\subsubsection{Well-Balanced Communication}

Brand positioning shapes customer perceptions. A brand needs to communicate its positioning to its target market. Awareness needs to be built, brand personality projected and favorable attitudes built and reinforced among customers. The brand theme needs to be reinforced by advertising, salespeople, sponsorship, public relations, and sales promotion campaigns.

\subsubsection{Being first}

In terms of success, the top positions to be held are by the pioneer brands rather than the follower brands. The brand which holds the first position often has a clear position in the minds of targeted customers before the competition starts. In such a way, pioneers are given an opportunity to create customers and distributors. But the condition is, it seeks maintained strength and efforts to resist attacks (Nyadzayo et al. 2018).

\subsubsection{Long-term perspective}

In order to make customers aware, exchange brand values as well as build customers, many years pass by. The brand investment shall be of high level and consistent. The deduction of investment will not result in a decline in the short term but, with respect to buying intentions, awareness levels, and brand associations, the brand equity will be diminished, Fouad and Wynn et al. (2017).

\subsubsection{Internal marketing}

The major focus of a number of corporate brands is to build a company brand. There are many service brands which are labeled as corporate brands. The communication with personnel is necessary as such service companies depend on the personal relation amid service users and the service providers. The values and strategies of the brand are must be discussed with the personnel (Magin and Huber et al. 2015). 


\section{2..4 Role of branding in brand development}

Branding is absolutely important for companies because of the overall impact it makes on a company. Branding can change how people perceive brands, it can drive a new business and brand. The most important reason for branding is important for businesses because that's how companies get recognition and will be known to consumers (Byrom, 2015). The brand is the most important element of trademarks, especially because of this aspect as it is actually the company's face. Therefore, professional logo designs should be powerful and easily memorable, which makes the impression of a man at first glance. Printed promotional products are a way to get this over. Branding is important when trying to create more business and brand-name branding can increase business value by giving the company more impact on the industry. This makes it a more attractive investment opportunity because it is a steady place in the market (Thomson and Crocker, 2015). Branding and advertising practices will reflect the brand and request its direct monitoring. Advertising strategies, such as the use of promotional products from trusted companies such as Outstanding Brands make it easy to create a coherent and attractive advertising strategy that fits your branding goals (Davis, 2017).

\subsection{Impact of branding on Consumer Choice}

As stated in the study of Khasawneh and Hasouneh (2010), customers are more likely to recognize the brand reputation while demographic features of customers have no important connection in their buying decisions that could impact on brand awareness. On the other hand, individuals are more likely to favor branded goods that have higher prices as they perceive that branded goods have more value as compared to local products.

Shehzad et al. (2014) stated that in order to achieve the brand means implementing marketing tackles for specific goods. If the brand is managed effectively, product and brand loyalty will also increase in the minds of customers. Retailers consider brands as collateral for customers that the product group will be similar to Coming as a result of this increased sales increase. Shehzad et al. (2014) argued that these brands to be used as valuable assets and attractive tricks to reach consumers for certain products. Business practices can be viewed with regard to brands, relationships, and loyalty.

Chinese people have unfriendly behavior for their own made brands, while in the UK, the products are marked superior to China. Female customers buying behavior is greatly influenced by market position, behavior toward a brand, and self-thoughts. Individuals are currently increasingly aware and engaged with distinct form of products. Numerous factors have a huge effect on female purchasing behavior. As indicated by Doostar, Abadi, and Abadi (2012) mark decency positively affects purchasing choices, clients Feel by statures of brand value out of the blue after using and after that will in general settle on purchasing choices, they use marks that is marginally mindful with its name and express esteem that this value has made for them. Measurements of brand reasonableness positively affect purchasing decisions.

\subsection{Empirical Literature}

\subsubsection{Branding strategies of Spotify and their impact on consumer choice (Hypothesis 1)}

Different from the 'dot.com period' when new businesses with worldwide yearnings propelled utilizing TV battles, Spotify's development has been a progressively unassuming methodology depending on word-of-mouth, PR and co-branding instead of huge promotion spending plans. At the point when the management went live in October 2008, it kept its free management welcome just, something that had been set up while it was in the last phases of improvement preceding open dispatch. Pietrobon and Dai (2012) argued that Spotify has utilized copromoting and organizations with distributors to build it are span by inserting distinctive arrangements of gadgets on different destinations. For instance, Drowned in Sound has a month to month playlist which it implants inside its blog which urges its readers to connect with Spotify.

A music magazine like NME offers applications with a scope of playlists which again will create mindfulness and commitment (Pietrobon and Dai, 2012). Other organization managements empower Festivals and Charities to draw in their group of onlookers through Spotify playlists. Notwithstanding the center music listening management Spotify has created different highlights to add to the estimation of the management which has additionally offered chances to spread consciousness of the site through co-branding. Spotify claims that users are highly advised that the average multiplatform of users spend 146 minutes per day using the service. Between 2013 and 2014, the share of users who listen to mobile phones tripled even if more than 50 percent of the meetings are still on the desktop (Pietrobon and Dai, 2012). 


\subsubsection{Branding strategies of Tidal and their impact on consumer choice (Hypothesis 2)}

Tidal propelled in an elegant manner, with a portion of music's most visible appearances including Madonna, Beyoncé, Alicia Keys, and Daft Punk. According to the estimates by Guardian, the account specialists who related themselves with the management have aggregate total assets of $\$ 2.5 \mathrm{bn}$. The Tidal management guarantees to give higher quality sound records to supporters, which Billboard reports will be at multiple times the bit rate of its rivals. At present, it has 25 million music tracks and in excess of 75,000 music recordings (Meier, 2017).

Tidal expects to be the head top of the line streaming management in the commercial center. It sees tremendous open doors in the sprouting gushing music industry to end up the go-to benefit for both the tolerant and most passionate audience. Tidal's solid ties and restrictive streaming manages such prominent craftsmen as Beyoncé, Prince, Jay Z, and Kanye West present the organization with special branding openings through both conventional TV and radio stages and also different electronic and internet-based life driven substance (Meier, 2017). The essential aim of this advertising effort is to speed up development of Tidal's supporter base ( 3 million right now), subsequently crossing over any barrier between industry pioneers Spotify (30 million) and Apple Music ( 8 million). Furthermore, insufficient has been done up to this point to feature Tidal's current victories and potential for a significantly more prominent piece of the overall industry going ahead. This battle will straightforwardly negate the counter Tidal suppositions investigated previously (Anderson, 2013).

Another objective of this advertising effort is to build Tidal's general perceivability in the commercial center, appealing both the casual audience and the more dedicated music fan. We plan to expand upon the organization's current Tidal's \#TidalForAll battle with a progressively far-reaching approach (Maasø, 2018).

Conventional and satellite radio ads will be propelled related to TV advertisements, online recordings, and an incorporated web-based life crusade using Twitter, Facebook, Instagram, and Snapchat. Online promoting will likewise comprise of spots on other streaming managements, for example, Yahoo Music, YouTube, and Pandora. There will be two ways to deal with the advertisements; recordings and stills of casual audience members making the most of their most loved music on Tidal, and advertisements where Tidal craftsmen are included advancing the benefits of the management, in particular, restrictive substance and prevalent sound and video quality (Maasø, 2018). This multi-faceted methodology will draw in undecided music fans by featuring Tidal's unmistakable qualities inside the business; higher quality sound and elite substance not accessible on other streaming management.

\subsubsection{Branding strategies of Apple Music and their impact on consumer choice (Hypothesis 3)}

As part of its brand strategy, Apple Music has acquired subscription music service Beats Music, as well as Beats Electronics where it makes popular Beats speakers, headphones, along with audio software. The company has acquired Beats due to its factor of becoming brand of choice within span of only five years in the sports and music world where the company had been the market leader in premium headphone market. After its acquisition, Apple is able to lead the revolution of digital music through its various products (Richtel and Chen, 2014).

According to the study conducted by Lieb (2013), the brand strategy of Apple is all about the experience. The study of Besharat (2010) also cited that emotional branding of Apple is felt in the minds and hearts of customers which are also considered as its key to survival. Apple's marking strategies, nevertheless, extend a long ways past simply advertising. The manner in which the organization presents their items with cautiously picked words, for example, 'the most slender ever', or 'the most developed yet' makes clients feel like they have the best item on the planet, paying little mind to whether this is in reality obvious. Indeed, Apple present highlights that most clients have had for quite a while however effectively influence it to appear as if they have recently designed the wheel. Solicitations to their press occasions are an ideal model, where their marking message of being imaginative is conveyed through the possibility that there is something customer have to know and be a part of (Burgess, 2012).

In 2012, Apple discharged this welcome for the dispatch of their third era iPad. The pun in their slogan 'We have something you truly need to see.' fills the group of onlookers with expectation, yet Apple is additionally offering a secretive piece of information here, about an element of the item they are going to dispatch. For this situation, the retina show of the iPad 3. The notable Apple logo is so shrewdly put on every one of their items, it gives others to access the room know precisely what mark you are utilizing. This is an aftereffect of a correction to the unconventional upside down introduction of the logo on their PCs (notepads) (Hracs, Jakob and Hauge, 2013). It was just in 1997 that Steve Jobs flipped it to be the correct route round for spectators, perceiving the significance of having others see the Apple logo the right far up as opposed to the PC client themselves. 


\subsection{Development of Theoretical Model}

Kinnunen et al., (2017) conducted a study to determine the relationship between branding and the consumer choice for the music streaming service. Therefore, the following hypothesis has been developed in line with this study:

H1: There is a significant relationship between branding strategies of Spotify and consumer choice

$\mathrm{H} 2$ : There is a significant relationship between the branding strategies of Apple Music and consumer choice

H3: There is a significant relationship between branding strategies of Tidal and consumer choice

\subsection{Summary}

It is concluded that firms that look like modern music distribution services appeared on the Internet in the mid1990s. The music streaming service providers including Apple, Spotify, and Tidal allowed the customers to choose the right tunes they need to hear. It is concluded that Apple Music brings users together. ITunes libraries with streaming services talk about the importance of unsurpassed musical behavior and the norms of taste and identity of the consumers located in it. However, music streaming services provided by Tidal and Spotify also adopted effective branding strategies to attract their users.

\section{Methodology}

\subsection{Introduction}

This is the third chapter of this study, which presents several aspects of methodological procedures. Several sections have been developed, and the first section presents the paradigm of research, for instance, qualitative, quantitative method and descriptive research. Meanwhile, the chapter includes a discussion of the tools and their implementation, data management, reliability, subjectivity, reliability, validity and positivity of the research.

\subsection{Research Paradigm}

This study examined the implementation of a research on actions since its purpose was to solve problems and implement actions. According to action-based research, this is a type of research that is done to identify key facts, problems and problems associated with a particular area or phenomenon, and then identify ways to eliminate them. The study consisted of a quantitative and qualitative methodology for the study of the main research questions. This study used the methodology of quantitative research since it has several advantages. Mackey, and Gass, (2015), stated that the quantitative research method should be used because it consists of data and triangulation from various sources, such as reviews and literature. Therefore, this study was taken an indepth discussion of the research outcomes.

Research is the most important aspect that requires, in an appropriate manner, certain opinions and beliefs that the author has already developed or previously developed in relation to research. In addition, the study is also based on the collection of quantitative data in the form of a survey. The characteristics of the quantitative methods are that uses information in numerical format. Another characteristic of the quantitative method is that it involves the use of measures and numbers (Taylor, Bogdan, and DeVault, 2015). This means that the figures are central and main factors when the nature of the research approach must be quantitative. According to Glesne, (2015), research and opinions, the theory of quantitative research focus on interrelated set of structures (variables) which can be in a form of sentences.

\subsection{Research Design}

In the field of scientific research, several research projects predominate, which are selected according to the criteria and objectives of the research questions. The main research projects include a research project, a correlation research project, design explanatory research, confirmatory design research, etc. However, in this study, the researcher chose a descriptive research project followed by a research paradigm called research. In this study, descriptive research design has been used where Lewis, (2015) stated that a descriptive study design refers to a design or method that includes the description and analysis of research designs. The advantage of developing descriptive research is that it is applicable in most of the research studies, while the main disadvantage of descriptive study is that it is sometimes distorted to suit the needs of the researcher, such as researcher cannot conduct experimentation or carry out research in the field. 
Consequently, the questionnaire collection, the researcher, can download questions to give readers the opportunity to respond in a certain way. Therefore, the researcher limits the participants to answer what is asked in the questionnaires or in the interviews (Glesne, 2015). However, in a positive start of the study, the researcher can obtain opinions and answers according to the study, which was established and defined in terms of its objectives and scope. It is for this reason that the design of the descriptive studies was chosen for the study which is best suitable based on research questions and objectives.

\subsection{Population and Sampling and Tools}

Using a focused sampling approach, the researcher used 80 music listeners which are music streaming service users to perform this research. The music listeners were the students of university. However, for the debate, it is important that directed sampling be a non-scientific sampling method, which allows the researcher to choose an option and control the sample with the same opportunities for participation of individuals (Flick, 2015). The survey was conducted with users of Apple Music, Spotify, and Tidal in the university. In addition, a survey questionnaire was also considered as a data collection tool. The questionnaire contained questions relating to brand strategies of Apple Music, Tidal, and Spotify. According to Vaioleti, (2016), the survey questions are small tools that are used to accept limited responses from participants. They contain measures of the Likert scale, which means that participants are given a certain scale or list of options.

The participant is obliged to choose any of these options. In this study, the researcher chose two types of data collection, which include primary and secondary data collection methods (Ledford, and Gast, 2018). In the primary data collection method, the researcher conducted a survey. In the same way, the researcher reviewed several research articles from Sage, Proquest, and EBSCO Host that helped to see the literature on the chosen topic.

\subsection{Data Analysis}

The survey data was analyzed using SPSS. The researcher must be rational in the interpretations, constantly respecting the importance of the participants and providing a full disclosure of the basis of any claim to analyze and interpret the data. Consequently, the method of data analysis, that is, the analysis of the survey (statistics), confirmed the integrity, impartiality, precision, value and reliability of the study (Smith, 2015). The regression analysis method is used for data analysis. While using regression analysis, researcher has aimed to test the hypothesis of the study. Regression analysis also helped in finding out the possible impact of independent variable (consumer choice) on dependent variable (branding strategies).

\subsection{Validity and Reliability}

Bauer, (2014), stated that credibility and reliability are decisive factors in the authenticity of a quantitative study. Reliability determines the number of times the test is performed and provides accurate results. In other words, the consistency and stability of test results or test results are reliability factors (Quinlan, Babin, Carr, and Griffin, 2019). Similarly, validity is also an associated term widely used in quantitative studies to describe the results that should have been tried and achieved. This shows that the measured factors were measured according to the criteria or requirements of the study. In this study, validity is maintained by checking the questionnaire again and again while conducting pilot testing of questionnaire to identify any possible mistakes, such as spelling errors or sentence structure.

Reality requires researchers to collect data that is relevant to the results of the statistical tests. According to the reliability of Panneerselvam, (2014), subjectivity and positioning are the main structures for quantitative research. Reliability refers to the reliability of the results obtained as a result of research, and similarly, subjectivity and positioning reflect the relevance and importance of the identified facts through quantitative approaches to data collection. In this study, reliability is maintained through Cronbach alpha which is a measure of reliability in statistical testing.

\subsection{Ethical Considerations}

The researcher ensured the confidentiality of the participants, who were the students of university. The participants were informed in advance about the objectives of the study. Consent forms were sent to the participants to develop trust among them with respect to the protection of their privacy. In addition to the primary data, the researcher used ethical guidelines to collect secondary data. In this sense, the researcher made a correct reference to the sources that were considered and used in this study (Mackey, and Gass, 2015). 
As a result, a reference list was also developed to provide credit and value to those whose work was used in the study. Another problem that a researcher usually faces is the participation of the respondents in relation to individual privacy rights. This is a problem that is related to the right of the participants to participate, the right to withdraw any right to continue the investigation, for example, the questionnaires of the surveys. To avoid this problem, the researcher informed the participants that they could leave at any time. Consequently, the participants were not coerced and answered the questions with their own will (Taylor, Bogdan, and DeVault, 2015). In addition, participants were eligible if they were not interested in the survey.

\subsection{Limitations and Delimitations}

The distinction between researches is the situation in which the researcher chooses control or establishes the limits of the research for a specific reason. According to Lewis (2015), the restrictions restrict the study and focus on the chosen aspect, which helps to avoid an excessive generalization of the conclusion. On the other hand, the study also included limitations. Due to restrictions such as resources, funds, time and availability of the respondents, the author chose a nominal amount of a sample of the population. Due to the lack of a population sample, the results may be related to the problem of reliability and reliability. Also, another limitation is that the researcher only access students as population of this study. Students who are customers and listeners of Apple Music, Tidal, and Spotify are approached through sampling.

\subsection{Summary}

It can be concluded that the research methodology is an important aspect that helped to carry out the research. The researcher adopted a quantitative methodology. The sample size was 80 participants. Meanwhile, the researcher also considered ethical principles to avoid any conflict in the future. The next chapter presents an analysis of the results.

\section{Results}

\subsection{Introduction}

This chapter provides the analysis of results. The responses of music listeners against the questions and selected companies have been discussed.

\subsection{Discussion on Results}

Are you a student?

\begin{tabular}{|c|c|c|c|c|c|}
\hline & & Frequency & Percent & Valid Percent & $\begin{array}{l}\text { Cumulative } \\
\text { Percent }\end{array}$ \\
\hline \multirow{3}{*}{ Valid } & Yes & 65 & 81.3 & 81.3 & 81.3 \\
\hline & No & 15 & 18.8 & 18.8 & 100.0 \\
\hline & Total & 80 & 100.0 & 100.0 & \\
\hline
\end{tabular}

The table given above presents status of participants if they were student. $81 \%$ of the students said 'yes' and remaining $18 \%$ said 'no'. This reveals that most of the participants were students who took part in the survey.

Are you a user of any music streaming services? (Apple Music, Spotify, Tidal)

\begin{tabular}{|l|l|l|l|l|}
\hline & Frequency & Percent & Valid Percent & $\begin{array}{l}\text { Cumulative } \\
\text { Percent }\end{array}$ \\
\hline Valid Yes & 80 & 100.0 & 100.0 & 100.0 \\
\hline
\end{tabular}

The table given above presents status of participants if they were using the music streaming services. All of the participants said 'yes'. This revealed that all of the participants were using music streaming services. 
Gender

\begin{tabular}{|ll|l|l|l|l|}
\hline & Frequency & Percent & Valid Percent & $\begin{array}{l}\text { Cumulative } \\
\text { Percent }\end{array}$ \\
\hline \multirow{2}{*}{ Valid } & Male & 38 & 47.5 & 47.5 & 47.5 \\
& Female & 42 & 52.5 & 52.5 & 100.0 \\
& Total & 80 & 100.0 & 100.0 & \\
\hline
\end{tabular}

The table presents gender of participants. $47 \%$ of the participants selected 'males' and remaining $52 \%$ selected 'female'. This reveals that most of the participants were females.

Age

\begin{tabular}{|ll|l|l|l|l|}
\hline & Frequency & Percent & Valid Percent & $\begin{array}{l}\text { Cumulative } \\
\text { Percent }\end{array}$ \\
\hline \multirow{4}{*}{ Valid } & 18-25 years & 60 & 75.0 & 75.0 & 75.0 \\
& $25-30$ & 18 & 21.8 & 21.8 & 96.8 \\
& 30 and over & 2 & 3.0 & 3.3 & 100.0 \\
& Total & 80 & 100.0 & 100.0 & \\
\hline
\end{tabular}

The table given above presents age of participants. The age of $75 \%$ of the participants was between 18 and 25 years. Age of 21\% was in between 30 and over. This reveals that most of the participants were aged between 18 and 25 years.

Qualification

\begin{tabular}{|ll|l|l|l|l|}
\hline & Frequency & Percent & Valid Percent & $\begin{array}{l}\text { Cumulative } \\
\text { Percent }\end{array}$ \\
\hline \multirow{2}{*}{ Valid } & High school diploma & 71 & 76.8 & 76.8 & 76.8 \\
& Bachelors degree & 9 & 11.3 & 11.3 & 100.0 \\
& Total & 80 & 100.0 & 100.0 & \\
\hline
\end{tabular}

The table given above presents qualification of participants. $76 \%$ of the students said 'high school diploma' and remaining $11 \%$ said 'bachelors degree'. This reveals that most of the participants were in high school diploma.

Have you heard of the following music streaming services; Apple Music, Spotify, Tidal?

\begin{tabular}{|l|l|l|l|l|}
\hline & Frequency & Percent & Valid Percent & $\begin{array}{l}\text { Cumulative } \\
\text { Percent }\end{array}$ \\
\hline Valid Yes & 80 & 100.0 & 100.0 & 100.0 \\
\hline
\end{tabular}

The table given above presents status of participants if they had listened the music streaming services such as Apple Music, Spotify and Tidal. All of the participants said 'yes'. This revealed that all of the participants had heard about the given music streaming services.

Do you use any of the following music streaming services? (Apple Music, Spotify, Tidal)

\begin{tabular}{|l|l|l|l|l|}
\hline & Frequency & Percent & Valid Percent & Cumulative Percent \\
\hline Valid Yes & 80 & 100.0 & 100.0 & 100.0 \\
\hline
\end{tabular}

The table given above presents status of participants if they were using music streaming services such as Apple Music, Spotify and Tidal. All of the participants said 'yes'. This revealed that all of the participants were using the given music streaming services. 
I prefer to use the music streaming services of ----- on daily basis.

\begin{tabular}{|cl|l|l|l|l|}
\hline & Frequency & Percent & Valid Percent & $\begin{array}{l}\text { Cumulative } \\
\text { Percent }\end{array}$ \\
\hline \multirow{2}{*}{ Valid } & Spotify & 53 & 66.3 & 66.3 & 66.3 \\
& Tidal & 1 & 1.3 & 1.3 & 67.5 \\
& Apple Music & 26 & 32.5 & 32.5 & 100.0 \\
& Total & 80 & 100.0 & 100.0 & \\
\hline
\end{tabular}

The table given above presents the preference of the use of music streaming services such as Apple Music, Spotify and Tidal. 66\% participants prefer to use the services of Spotify. $1 \%$ preferred to use the services of Tidal. 32\% prefer to use the services of Apple Music on daily basis. The figures reveale that most of the participants were using the music streaming services of Spotify.

I purchase music streaming services of -----

\begin{tabular}{|ll|l|l|l|l|}
\hline & Frequency & Percent & Valid Percent & $\begin{array}{l}\text { Cumulative } \\
\text { Percent }\end{array}$ \\
\hline \multirow{2}{*}{ Valid } & Tidal & 15 & 18.8 & 18.8 & 18.8 \\
& Spotify & 34 & 42.5 & 42.5 & 61.3 \\
& Apple Music & 31 & 38.8 & 38.8 & 100.0 \\
& Total & 80 & 100.0 & 100.0 & \\
\hline
\end{tabular}

The table given above presents the purchase of music streaming services such as Apple Music, Spotify and Tidal. $42 \%$ participants prefer to purchase the services of Spotify. $15 \%$ preferred to purchase the services of Tidal. 38\% purchase the services of Apple Music. The figures revealed that most of the participants were purchasing the music streaming services of Spotify.

I would pay maximum amount of money to listen to an album by my favourite artist/band on -----

\begin{tabular}{|ll|l|l|l|l|}
\hline & Frequency & Percent & Valid Percent & $\begin{array}{l}\text { Cumulative } \\
\text { Percent }\end{array}$ \\
\hline \multirow{2}{*}{ Valid } & Tidal & 14 & 17.5 & 17.5 & 17.5 \\
& Apple Music & 27 & 33.8 & 33.8 & 51.3 \\
& Spotify & 39 & 48.8 & 48.8 & 100.0 \\
& Total & 80 & 100.0 & 100.0 & \\
\hline
\end{tabular}

The table given above presents the willingness of participants to pay for listening the favourite music album. 48\% participants preferred for Spotify. 17\% preferred Tidal. 33\% preferred Apple Music. The figures reveal that most of the participants were preferred Spotify

I think the music brands ------ has good quality.

\begin{tabular}{|ll|l|l|l|l|}
\hline & & Frequency & Percent & Valid Percent & $\begin{array}{l}\text { Cumulative } \\
\text { Percent }\end{array}$ \\
\hline \multirow{2}{*}{ Valid } & Tidal & 15 & 18.8 & 18.8 & 18.8 \\
& Apple Music & 28 & 35.0 & 35.0 & 53.8 \\
& Spotify & 37 & 46.3 & 46.3 & 100.0 \\
& Total & 80 & 100.0 & 100.0 & \\
\hline
\end{tabular}


The table given above presents the thought of participants about the quality of music brands. $46 \%$ participants preferred for Spotify. 18\% preferred Tidal. 35\% preferred Apple Music. The figures reveal that most of the participants were preferred Spotify.

----- provides more individualised music services

\begin{tabular}{|ll|l|l|l|l|}
\hline & Frequency & Percent & Valid Percent & $\begin{array}{l}\text { Cumulative } \\
\text { Percent }\end{array}$ \\
\hline \multirow{2}{*}{ Valid } & Tidal & 12 & 15.0 & 15.0 & 15.0 \\
& Apple Music & 28 & 35.0 & 35.0 & 50.0 \\
& Spotify & 40 & 50.0 & 50.0 & 100.0 \\
& Total & 80 & 100.0 & 100.0 & \\
\hline
\end{tabular}

The table given above presents the thought of participants about the individualized music services of the three brands. 50\% participants preferred for Spotify. 15\% preferred Tidal. 35\% preferred Apple Music. The figures reveal that most of the participants preferred Spotify.

Interface of the streaming company ----- has more attraction.

\begin{tabular}{|ll|l|l|l|l|}
\hline & Frequency & Percent & Valid Percent & $\begin{array}{l}\text { Cumulative } \\
\text { Percent }\end{array}$ \\
\hline \multirow{4}{*}{ Valid } & Tidal & 19 & 23.8 & 23.8 & 23.8 \\
& Apple Music & 19 & 23.8 & 23.8 & 47.5 \\
& Spotify & 42 & 52.5 & 52.5 & 100.0 \\
& Total & 80 & 100.0 & 100.0 & \\
\hline
\end{tabular}

The table given above presents the thought of participants about the attractiveness of interface of three brands. $52 \%$ participants preferred for Spotify. 23\% preferred Tidal. 23\% preferred Apple Music. The figures reveal that most of the participants preferred Spotify.

Besides me, the branding of ------ plays an important role in my buying decisions.

\begin{tabular}{|ll|l|l|l|l|}
\hline & & Frequency & Percent & Valid Percent & $\begin{array}{l}\text { Cumulative } \\
\text { Percent }\end{array}$ \\
\hline \multirow{2}{*}{ Valid } & Tidal & 19 & 23.8 & 23.8 & 23.8 \\
& Apple Music & 27 & 33.8 & 33.8 & 57.5 \\
& Spotify & 34 & 42.5 & 42.5 & 100.0 \\
& Total & 80 & 100.0 & 100.0 & \\
\hline
\end{tabular}

The table given above presents the responses of participants about the role of branding in buying decisions pertaining to the services of three brands. $42 \%$ participants preferred for Spotify. $23 \%$ preferred Tidal. $32 \%$ preferred Apple Music. The figures reveal that most of the participants preferred Spotify in their buying decisions followed by the branding of company. 
Branding of which streaming services attracts you more. Please select the given options

\begin{tabular}{|ll|l|l|l|l|}
\hline & Frequency & Percent & Valid Percent & $\begin{array}{l}\text { Cumulative } \\
\text { Percent }\end{array}$ \\
\hline \multirow{4}{*}{ Valid } & Tidal & 11 & 13.8 & 13.8 & 13.8 \\
& Apple Music & 31 & 38.8 & 38.8 & 52.5 \\
& Spotify & 38 & 47.5 & 47.5 & 100.0 \\
& Total & 80 & 100.0 & 100.0 & \\
\hline
\end{tabular}

The table given above presents the response of participants about the attractiveness branding of the three brands. $47 \%$ participants preferred for Spotify. 38\% preferred Tidal. 13\% preferred Apple Music. The figures reveal that most of the participants preferred Spotify.

I use ----- because it has better quality of sound for streaming services versus the two others.

\begin{tabular}{|ll|l|l|l|l|}
\hline & & Frequency & Percent & Valid Percent & Cumulative Percent \\
\hline \multirow{4}{*}{ Valid } & Tidal & 16 & 20.0 & 20.0 & 20.0 \\
& Apple Music & 26 & 32.5 & 32.5 & 52.5 \\
& Spotify & 38 & 47.5 & 47.5 & 100.0 \\
& Total & 80 & 100.0 & 100.0 & \\
\hline
\end{tabular}

The table given above presents the response of participants about the quality of sound as a reason of preference to the other two brands. $47 \%$ participants preferred for Spotify. $20 \%$ preferred Tidal. $32 \%$ preferred Apple Music. The figures reveal that most of the participants preferred Spotify.

I approach the internet and access the music services of ------ , because it contains more melodies.

\begin{tabular}{|ll|l|l|l|l|}
\hline & Frequency & Percent & Valid Percent & $\begin{array}{l}\text { Cumulative } \\
\text { Percent }\end{array}$ \\
\hline \multirow{4}{*}{ Valid } & Tidal & 10 & 12.5 & 12.5 & 12.5 \\
& Apple Music & 26 & 32.5 & 32.5 & 45.0 \\
& Spotify & 44 & 55.0 & 55.0 & 100.0 \\
& Total & 80 & 100.0 & 100.0 & \\
\hline
\end{tabular}

The table given above presents the response of participants about the presence of melodies as a reason of preference to the other two brands. 55\% participants preferred for Spotify. $12 \%$ preferred Tidal. $32 \%$ preferred Apple Music. The figures reveal that most of the participants preferred Spotify.

Do you think the branding of ------ is the most important factor for retaining the existing customers.

\begin{tabular}{|ll|l|l|l|l|}
\hline & Frequency & Percent & Valid Percent & Cumulative Percent \\
\hline \multirow{4}{*}{ Valid } & Tidal & 11 & 13.8 & 13.8 & 13.8 \\
& Apple Music & 22 & 27.5 & 27.5 & 41.3 \\
& Spotify & 47 & 58.8 & 58.8 & 100.0 \\
& Total & 80 & 100.0 & 100.0 & \\
\hline
\end{tabular}

The table given above presents the response of participants about the value of branding in retaining the existing customers at the three brands. 58\% participants preferred for Spotify. 13\% preferred Tidal. 27\% preferred Apple Music. The figures reveal that most of the participants preferred Spotify. 
Branding of which of the given companies allows them to differentiates themselves.

\begin{tabular}{|ll|l|l|l|l|}
\hline & Frequency & Percent & Valid Percent & $\begin{array}{l}\text { Cumulative } \\
\text { Percent }\end{array}$ \\
\hline \multirow{2}{*}{ Valid } & Tidal & 21 & 26.3 & 26.3 & 26.3 \\
& Apple Music & 26 & 32.5 & 32.5 & 58.8 \\
& Spotify & 33 & 41.3 & 41.3 & 100.0 \\
& Total & 80 & 100.0 & 100.0 & \\
\hline
\end{tabular}

The table given above presents the response of participants about the role branding in differentiating the three brands. $41 \%$ participants preferred for Spotify. 26\% preferred Tidal. 33\% preferred Apple Music. The figures reveal that most of the participants preferred Spotify.

I have a positive brand image of ------ in my mind

\begin{tabular}{|ll|l|l|l|l|}
\hline & Frequency & Percent & Valid Percent & $\begin{array}{l}\text { Cumulative } \\
\text { Percent }\end{array}$ \\
\hline \multirow{4}{*}{ Valid } & Tidal & 13 & 16.3 & 16.3 & 16.3 \\
& Apple Music & 29 & 36.3 & 36.3 & 52.5 \\
& Spotify & 38 & 47.5 & 47.5 & 100.0 \\
& Total & 80 & 100.0 & 100.0 & \\
\hline
\end{tabular}

The table given above presents the image of given three brands in the mind of participants. $47 \%$ participants preferred for Spotify. 36\% preferred Tidal. 16\% preferred Apple Music. The figures reveal that most of the participants preferred Spotify.

I remember the tagline of ------ brand's music streaming services

\begin{tabular}{|ll|l|l|l|l|}
\hline & Frequency & Percent & Valid Percent & $\begin{array}{l}\text { Cumulative } \\
\text { Percent }\end{array}$ \\
\hline \multirow{4}{*}{ Valid } & Tidal & 18 & 22.5 & 22.5 & 22.5 \\
& Spotify & 33 & 41.3 & 41.3 & 63.8 \\
& Apple Music & 29 & 36.3 & 36.3 & 100.0 \\
& Total & 80 & 100.0 & 100.0 & \\
\hline
\end{tabular}

The table given above presents the tagline of given three brands in the mind of participants. $41 \%$ participants preferred for Spotify. 22\% preferred Tidal. 36\% preferred Apple Music. The figures reveal that most of the participants preferred Spotify.

I like the brand logo of ------ music streaming services

\begin{tabular}{|ll|l|l|l|l|}
\hline & Frequency & Percent & Valid Percent & $\begin{array}{l}\text { Cumulative } \\
\text { Percent }\end{array}$ \\
\hline \multirow{2}{*}{ Valid } & Tidal & 10 & 12.5 & 12.5 & 12.5 \\
& Apple Music & 29 & 36.3 & 36.3 & 48.8 \\
& Spotify & 41 & 51.3 & 51.3 & 100.0 \\
& Total & 80 & 100.0 & 100.0 & \\
\hline
\end{tabular}

The table given above presents the preference of logo three brands by the participants. 51\% participants preferred for Spotify. 12\% preferred Tidal. 36\% preferred Apple Music. The figures reveal that most of the participants preferred Spotify. 


\subsubsection{Regression 01}

H1: There is a significant relationship between branding strategies of Spotify and consumer choice

ANOVA $A^{a}$

\begin{tabular}{|rl|r|r|r|r|r|}
\hline Model & & Sum of Squares & df & Mean Square & F & \multicolumn{1}{c|}{ Sig. } \\
\hline \multirow{2}{*}{1} & Regression & 43.200 & 1 & 43.200 & .527 & $.015^{\mathrm{b}}$ \\
& Residual & .000 & 78 & .000 & & \\
& Total & 43.200 & 79 & & & \\
\hline
\end{tabular}

a. Dependent Variable: Customer Choice To Spotify Music Services-DV

b. Predictors: (Constant), Branding Strategies -IV

Significance value of 0.015 indicates that the relationship is significant. As the value is lower than 0.05.

Coefficients $^{a}$

\begin{tabular}{|c|c|c|c|c|c|}
\hline \multirow[t]{2}{*}{ Model } & \multicolumn{2}{|c|}{ Unstandardized Coefficients } & \multirow{2}{*}{$\begin{array}{c}\text { Standardized } \\
\text { Coefficients }\end{array}$} & \multirow[t]{2}{*}{$\mathrm{t}$} & \multirow[t]{2}{*}{ Sig. } \\
\hline & B & Std. Error & & & \\
\hline (Constant) & .000 & .000 & & .527 & $.015^{\mathrm{b}}$ \\
\hline Branding Strategies -IV & 1.000 & .000 & 1.000 & & \\
\hline
\end{tabular}

a. Dependent Variable: Customer Choice To Spotify Music Services-DV

The sig. values of both dependent and independent variable are under 0.05 . On the basis of this, it could be stated that hypothesis has been accepted. Hence, a change in the branding strategies would result in the customer choice against the streaming services of Spotify.

\subsubsection{Regression 02}

$\mathrm{H} 2$ : There is a significant relationship between the branding strategies of Apple Music and consumer choice ANOVA $A^{a}$

\begin{tabular}{|rl|r|r|r|r|r|}
\hline Model & & Sum of Squares & df & Mean Square & F & \multicolumn{1}{c|}{ Sig. } \\
\hline \multirow{2}{*}{1} & Regression & 1.481 & 1 & 1.481 & 1.535 & $.219^{\mathrm{b}}$ \\
& Residual & 75.269 & 78 & .965 & & \\
& Total & 76.750 & 79 & & & \\
\hline
\end{tabular}

a. Dependent Variable: Customer Choice To Apple Music Service -DV

b. Predictors: (Constant), Branding Strategies -IV

Significance value of 0.219 indicates that the relationship is not significant. As the value is above 0.05 .

\section{Coefficients $^{a}$}

\begin{tabular}{|c|c|c|c|c|c|}
\hline \multirow[t]{2}{*}{ Model } & \multicolumn{2}{|c|}{ Unstandardized Coefficients } & \multirow{2}{*}{$\begin{array}{c}\begin{array}{c}\text { Standardized } \\
\text { Coefficients }\end{array} \\
\text { Beta }\end{array}$} & \multirow[t]{2}{*}{$\mathrm{t}$} & \multirow[t]{2}{*}{ Sig. } \\
\hline & B & Std. Error & & & \\
\hline (Constant) & 3.940 & .667 & & 5.909 & .000 \\
\hline Branding Strategies -IV & -.185 & .149 & -.139 & -1.239 & .219 \\
\hline
\end{tabular}

a. Dependent Variable: Customer Choice To Apple Music Service -DV 
The sig. values of both dependent and independent variable are different. On the basis of this, it could be stated that hypothesis has been not been accepted. Hence, a change in the branding strategies would not result in the customer choice against the streaming services of Apple Music.

\subsubsection{Regression 03}

H3: There is a significant relationship between branding strategies of Tidal and consumer choice

ANOVA ${ }^{a}$

\begin{tabular}{|rl|r|r|r|r|r|}
\hline Model & & Sum of Squares & Df & Mean Square & F & \multicolumn{1}{c|}{ Sig. } \\
\hline \multirow{2}{*}{1} & Regression & .208 & 1 & .208 & .192 & $.562^{\mathrm{b}}$ \\
& Residual & 84.542 & 78 & 1.084 & & \\
& Total & 84.750 & 79 & & & \\
\hline
\end{tabular}

a. Dependent Variable: Customer Choice To Tidal Music Service -DV

b. Predictors: (Constant), Branding Strategies -IV

Significance value of 0.562 indicates that the relationship is not significant. As the value is above 0.05 .

\section{Coefficients ${ }^{a}$}

\begin{tabular}{|c|c|c|c|c|c|}
\hline \multirow[t]{2}{*}{ Model } & \multicolumn{2}{|c|}{ Unstandardized Coefficients } & \multirow{2}{*}{$\begin{array}{c}\text { Standardized } \\
\text { Coefficients }\end{array}$} & \multirow[t]{2}{*}{$\mathrm{t}$} & \multirow[t]{2}{*}{ Sig. } \\
\hline & B & Std. Error & & & \\
\hline (Constant) & 2.181 & .707 & & 3.086 & .003 \\
\hline Branding Strategies -IV & -.069 & .158 & -.050 & -.438 & .562 \\
\hline
\end{tabular}

a. Dependent Variable: Customer Choice To Tidal Music Service -DV

The sig. values of both dependent and independent variable are different from each other. On the basis of this, it could be stated that hypothesis has been not accepted. Hence, a change in the branding strategies would not result in the customer choice against the streaming services of Tidal.

\subsection{Discussion on Findings}

\subsubsection{Theme \#1: Scope of Branding Strategies}

The music industry was aware of a number of technological inventions in the past few decades. This industry has continuously been reinventing ever since the vinyl, the radio, and CDs were invented. All these inventions are considered to be maintaining inventions. When the industry digitalized, it destroyed many existing business models. This recovery is being made through new business models which tends to generate income on the internet. In the beginning, payment was made on per album or per track basis but now, it is being made on the basis of interactive streaming, Leyshon and Thrift et al. (2016).

In order to create a brand, it is necessary to increase the distinct values of a core product so as to make it indifferent from the competition. Also, the comprehension of emotional as well as functional values of the customers shall be pin pointed. There are seven factors in creating a brand:

\subsubsection{Quality}

In order to create a unique position in the market, the targeted market shall be chosen carefully which would eventually draw a different picture in the customer's minds. The brand name, delivery, image, packaging, service, guarantees, and design are a few things which help to achieve this, Iyer and Davari (2018).

\subsection{Summary}

Based on the results, it could be summarized that most the responses of participants were oriented towards Spotify. In regards to the preferences of music streaming services, Spotify lied on the first preference. 
Meanwhile, Apple Music lied at the second number. Whereas, Tidal lied on the third number followed by a minimal amount of responses for its services chosen by the consumers.

\section{Conclusion}

The aim of this study was to evaluate the impact of branding in the music streaming industry while considering the three companies such as Spotify, Tidal and Apple Music. Following were the aims of study.

- To examine the importance of branding in music streaming services

- To evaluate the branding strategies of music streaming services such as such as Spotify, Apple Music, and Tidal

- To evaluate the preference of consumers for the use of any three companies followed by their branding

It is concluded that the branding has main stake in the music streaming services industry. The music industry is aware of a number of technological inventions since the past few decades. This industry has been reinventing ever since the vinyl, the radio, and CDs were invented. All these inventions are considered to be maintaining the inventions in the sector. Although the inventions add value, the branding could not be avoided. Branding gives name and fame to the brands and develops awareness amongst the participants. When the industry digitalized followed by the innovations, it destroyed many existing business models. This recovery is being made through new business models which tends to generate income on the internet. The findings revealed that branding is used by the music streaming services including Spotify, Apple Music and Tidal. Spotify is more successful in attracting the new customers as per the responses from the participants.

It is concluded that Apple branding strategy for the music streaming services takes some great things. It is focused exclusively on high-quality products. Apple does not sell cheaper models of a smartphone Apple. Apple made its users who are not ready to opt any other competitive brand than apple or are highly satisfied with Apple. The prices of streaming services of Apple Music are maintained very high which portrays a curious image in the people's minds. The services of Apple Music are always sleek and attractive. Moreover, the interface used in advertising are also very attractive.

However, the findings from survey do not reveal same findings from literature. The responses revealed that quality of interface of Apple music lied on second versus Tidal followed by Spotify. It is concluded that there are several bloggers who often disclose the latest news about Apple Music, Tidal and Spotify. Yet there is a huge sum of people who constantly try to figure out the shape and specifications of the streaming services of Spotify.

It is also concluded that Spotify is a freemium service, which offers free basics with ads. However, other features such as better streaming and music downloads are offered with paid subscriptions. The unique value proposition of Spotify is to offer users a complete control while allowing them to access the songs on demand. The company also provide a free option which offered greater than simple streaming in radio style. Spotify revolutionized how people listened to music and therefore, it has been highly preferred by the listeners of music streaming services. It became popular with consumer music services because it puts the management in the hands of the users. It also allows them to select specific songs and create playlists. The similar features existed in Tidal and Apple Music do not attract the music listeners. Spotify is preferred as it allows the users to upload local laws so they did not have to leave their own libraries and playlists behind to make the Spotify. Spotify fills the need for consumers but is able to control its growth. In the beginning, Tidal was positioned as an artist owned service.

The evaluation of branding of three brands such as Tidal, Apple Music and Spotify indicate the differing results. Spotify Music is found more successful in occupying its image in mind of music listeners. The company provides more individualized services with high quality to the participants. The findings also suggest that Tidal and Apple Music have good branding and its impact on the consumers. However, Tidal followed by Apple Music has lower impact when it comes to compare the results and responses with Spotify.

\section{References}

Anderson, T., (2013). From Background Music to Above-the-Line Actor: The Rise of the Music Supervisor in Converging Televisual Environments. Journal of Popular Music Studies, 25(3), pp.371-388.

Besharat, A., (2010). How co-branding versus brand extensions drive consumers' evaluations of new products: A brand equity approach. Industrial Marketing Management, 39(8), pp.1240-1249.

Brown, S. (2016). Brands and Branding. London: SAGE . 
Burgess, J., (2012). The iPhone moment, the Apple brand, and the creative consumer: From "hackability and usability" to Cultural Generativity. In Studying Mobile Media (pp. 36-50). Routledge.

Byrom, J., (2015). Rethinking Place Branding: Comprehensive Brand Development for Cities and Regions. JOURNAL OF PLACE MANAGEMENT AND DEVELOPMENT, 8(2).

Chen, Y.M., Liu, H.H. \& Chiu, Y.C., (2017). Customer benefits and value creation in streaming services marketing: a managerial cognitive capability approach. Psychology \& Marketing, 34(12), pp.11011108 .

Davcik, N.S., Vinhas da Silva, R. \& Hair, J.F., (2015). Towards a unified theory of brand equity: conceptualizations, taxonomy and avenues for future research. Journal of Product \& Brand Management, 24(1), pp.3-17.

Davis, M., (2017). The fundamentals of branding. Bloomsbury Publishing.

Doostar, M., Akhlagh, M. \& Abadi, I., (2012). Analysis of the Impact Brand Assets on the Buying Decisions of Final Consumers Brand of Iran's Milk Industry Company (Pegah). Journal of Basic and Applied Scientific Research, 2(9), pp.8824-8832.

Fang, Y. H. (2018). An app a day keeps a customer connected: Explicating loyalty to brands and branded applications through the lens of affordance and service-dominant logic. Information \& Management.

Flick, U., (2015). Introducing research methodology: A beginner's guide to doing a research project. Sage.

Fouad, M.N., Wynn, T.A., Scribner, R., Schoenberger, Y.M.M., Antoine-Lavigne, D., Eady, S., Anderson, W.A. \& Bateman, L.B., (2017). Introduction: Impacting the Social Determinants of Health through a Regional Academic-Community Partnership: The Experience of the Mid-South Transdisciplinary Collaborative Center for Health Disparities Research. Ethnicity \& disease, 27(Suppl 1), p.277.

Frew, M. \& McPherson, G., (2015). The brand in music: Entrepreneurship, emotion and engagement. Music entrepreneurship, pp.241-268.

Gerogiannis, C. V., Maftei, A. V., \& Papageorgiou, I. E. (2016). Critical Success Factors of Online Music Streaming Services-A Case Study of Applying the Fuzzy Cognitive Maps Method. In Conference paper (pp. 1077-1084).

Glantz, M., (2016). Internet Radio Adopts a Human Touch: A Study of 12 Streaming Music Services. Journal of Radio \& Audio Media, 23(1), pp.36-49.

Glesne, C., (2015). Becoming qualitative researchers: An introduction. Pearson.

Gomes, M., Fernandes, T. \& Brandão, A., (2016). Determinants of brand relevance in a B2B service purchasing context. Journal of Business \& Industrial Marketing, 31(2), pp.193-204.

Hracs, B. J., \& Jansson, J. (2017). Death by streaming or vinyl revival? Exploring the spatial dynamics and value-creating strategies of independent record shops in Stockholm. Journal of Consumer Culture, 1469540517745703.

Hracs, B.J., Jakob, D. \& Hauge, A., (2013). Standing out in the crowd: The rise of exclusivity-based strategies to compete in the contemporary marketplace for music and fashion. Environment and Planning A, 45(5), pp.1144-1161.

Iyer, P., Davari, A. \& Paswan, A., (2018). Determinants of brand performance: the role of internal branding. Journal of Brand Management, 25(3), pp.202-216.

Khasawneh, K. \& Hasouneh, A.B.I., (2010). The effect of familiar brand names on consumer behaviour: A Jordanian Perspective. International Research Journal of Finance and Economics, 43(1), pp.34-57.

Kim, J., Nam, C., \& Ryu, M. H. (2017). What do consumers prefer for music streaming services?: A comparative study between Korea and US. Telecommunications Policy, 41(4), 263-272.

Kim, S., Kim, I., \& Hyun, S. S. (2016). First-Class in-Flight Services and Advertising Effectiveness: Antecedents of Customer-Centric Innovativeness and Brand Loyalty in the United States (US) Airline Industry. Journal of Travel \& Tourism Marketing, 33(1), 118-140.

Ledford, J.R. \& Gast, D.L., (2018). Single case research methodology: Applications in special education and behavioral sciences. Routledge.

Lee, M., Choi, H., Cho, D. \& Lee, H., (2016). Cannibalizing or Complementing?. The Impact of Online Streaming Services on Music Record Sales. Procedia Computer Science, 91, pp.662-671. 
Lewis, S., (2015). Qualitative inquiry and research design: Choosing among five approaches. Health promotion practice, 16(4), pp.473-475.

Leyshon, A., Thrift, N., Crewe, L., French, S. \& Webb, P., (2016). Leveraging affect: Mobilising enthusiasm and the co-production of the musical economy. The production and consumption of music in the digital age. London: Routledge, pp.248-62.

Leyshon, A., Thrift, N., Crewe, L., French, S., \& Webb, P. (2016). 18 Leveraging Affect. The Production and Consumption of Music in the Digital Age, 58, 248.

Lieb, K.J., (2013). Gender, branding, and the modern music industry: The social construction of female popular music stars. Routledge.

Liu, R.R. \& Zhang, J., (2017). An Empirical Study of the Impact of Social Media on Consumer Music Advocacy.

Maasø, A., (2018). Music streaming, festivals, and the eventization of music. Popular Music and Society, 41(2), pp.154-175.

Mackey, A. \& Gass, S.M., (2015). Second language research: Methodology and design. Routledge.

Magin, S., Huber, F. \& Herrmann, A., (2015). Determinants of Teenagers' Brand Buying BehaviorDevelopment of a Structural Equation Model. In New Meanings for Marketing in a New Millennium (pp. 12-16). Springer, Cham.

Masuda, J.R. \& Bookman, S., (2018). Neighbourhood branding and the right to the city. Progress in Human Geography, 42(2), pp.165-182.

McDowell, W.S., (2015). Emerging industry issues and trends influencing the branding of media content. In Handbook of media branding (pp. 145-156). Springer, Cham.

Meier, L.M., (2017). Popular music as promotion: Music and branding in the digital age. John Wiley \& Sons.

Meier, L.M., (2017). Popular music as promotion: Music and branding in the digital age. John Wiley \& Sons.

Mooney, C. (2015). Music and Video Streaming. New York: The Rosen Publishing Group. Wlomert, N., \& Papies, D. (2016). On-demand streaming services and music industry revenues - insights from Spotify's market entry. International Journal of Research in Marketing, 33(2), 314-327.

Naveed, K., Watanabe, C. \& Neittaanmäki, P., (2017). Co-evolution between streaming and live music leads a way to the sustainable growth of music industry-Lessons from the US experiences. Technology in Society, 50, pp.1-19.

Nyadzayo, M.W., Matanda, M.J. \& Rajaguru, R., (2018). The determinants of franchise brand loyalty in B2B markets: An emerging market perspective. Journal of Business Research, 86, pp.435-445.

Ottman, J., (2017). The new rules of green marketing: Strategies, tools, and inspiration for sustainable branding. Routledge.

Panneerselvam, R., (2014). Research methodology. PHI Learning Pvt. Ltd.

Philpott, M. \& Doran, J., (2016). Ensuring Quality of Experience in the Connected Home: A New Battleground for Quality of Experience Differentiation. Fiber and Integrated Optics, 35(2), pp.86-93.

Pietrobon, A. \& Dai, Y., (2012). Branding for Start-ups: A case Study of Spotify.

Quinlan, C., Babin, B., Carr, J. \& Griffin, M., (2019. Business research methods. South Western Cengage.

Richtel, M. \& Chen, B.X., (2014). Tim Cook-Making Apple His Own. New York Times, Technology, 15.

Saboo, A.R., Kumar, V. \& Ramani, G., (2016). Evaluating the impact of social media activities on human brand sales. International Journal of Research in Marketing, 33(3), pp.524-541.

Shehzad, U., Ahmad, S., Iqbal, K., Nawaz, M. \& Usman, S., (2014). Influence of Brand Name on Consumer Choice \& Decision. IOSR Journal of Business and Management (IOSR-JBM), 16(6), pp.72-76.

Smith, J.A. ed., (2015). Qualitative psychology: A practical guide to research methods. Sage.

Taylor, S.J., Bogdan, R. \& DeVault, M., (2015). Introduction to qualitative research methods: A guidebook and resource. John Wiley \& Sons.

Taylor, S.J., Bogdan, R. \& DeVault, M., (2015). Introduction to qualitative research methods: A guidebook and resource. John Wiley \& Sons.

Thomson, D.M. \& Crocker, C., (2015). Application of conceptual profiling in brand, packaging and product development. Food Quality and Preference, 40, pp.343-353. 
Truong, Y., Klink, R. R., Simmons, G., Grinstein, A., \& Palmer, M. (2017). Branding strategies for hightechnology products: The effects of consumer and product innovativeness. Journal of Business Research, 70, 85-91.

Truong, Y., Klink, R.R., Simmons, G., Grinstein, A. \& Palmer, M., (2017). Branding strategies for hightechnology products: The effects of consumer and product innovativeness. Journal of Business Research, 70, pp.85-91.

Vaioleti, T.M., (2016). Talanoa research methodology: A developing position on Pacific research. Waikato Journal of Education, 12(1).

\section{Appendix}

Questionnaire

1. Are you a student? (If yes, then move to the next question)

- Yes

- $\quad$ No

2. Are you a user of any music streaming services? (Apple Music, Spotify, Tidal)

- Yes

- No

3. Your Gender

- Male

- Female

4. Your Age

- 18-25 years

- $25-30$

- 30 and over

5. Your Qualification

- High school diploma

- Bachelors degree

- None

6. Have you heard of the following music streaming services; Apple Music, Spotify, Tidal?

- Yes

- No $^{2}$

7. Do you use any of the following music streaming services? (Apple Music, Spotify, Tidal)

- Yes

- No 
Please tick the response, you think is most appropriate as per your preference, where (1= Spotify, $2=$ Apple, $3=$ Tidal)

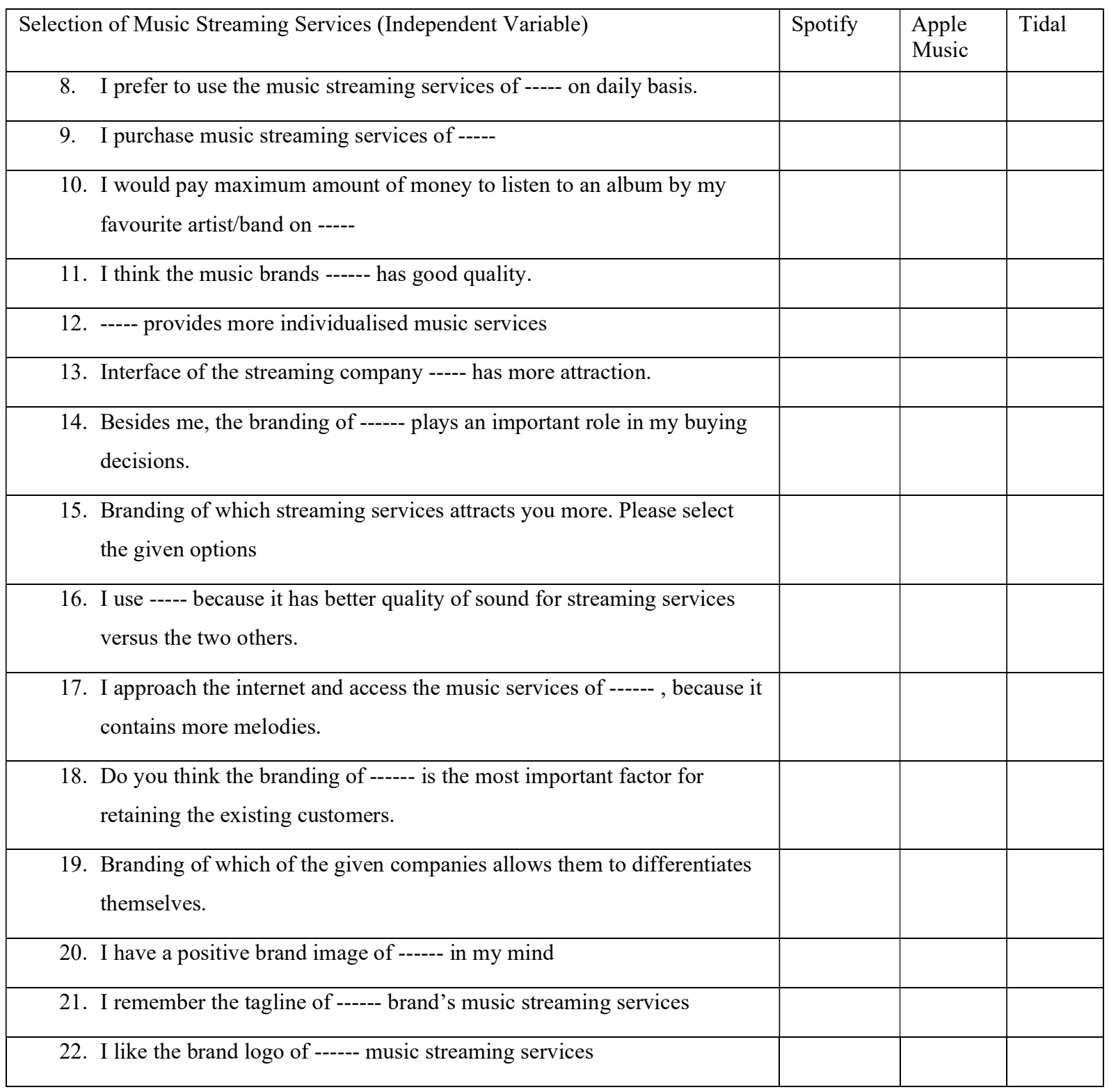

